\title{
Writing Russian History in Nazi Germany: the Case of Viktor Vladimirovich Leontovitsch (Part Two)
}

\author{
G. Hamburg
}

For citation: Hamburg G. Writing Russian History in Nazi Germany: the Case of Viktor Vladimirovich Leontovitsch (Part Two). Vestnik of Saint Petersburg University. History, 2018, vol. 63, issue 2, pp. 572-596. https://doi.org/10.21638/11701/spbu02.2018.215

The distinguished historian Victor Vladimirovich Leontovitsch (1902-1959) was little known before the 1957 publication of his classic book Geschichte des Liberalismus in Russland [A History of Liberalism in Russia]. Since then, Leontovitsch's capital work has been translated into major European languages: first, into Russian (in 1980), then into French (in 1987), and finally, into English (in 2012). Western historians widely reviewed Leontovitsch's history of liberalism on its initial publication, but few reviews mentioned Leontovitsch's previous scholarship, and none endeavored to explain the connections between the earlier work and his study of liberalism. This two-part article, drawing on printed and archival sources, explores Leontovitsch's intellectual roots, his life and his creative activity from 1902 to 1947. It examines his view of Russian history, particularly, his conception of the interplay between law and politics in the reign of Ivan IV; his attitude toward Russian Orthodoxy; his attitude toward the French Revolution; his hostility to National Socialism and Nazi policy. This article also offers new material on the history of the post-1917 Russian emigration in Central Europe: it deals with Leontovitsch's teachers in the Russian Faculty of Law in Prague, and also discusses his ties in the 1930s and 1940s with important emigré intellectuals, such as Aleksandr Makarov, Dmitrii Chizhevskii, and Fedor Stepun.

Keywords: Leontovitsch, Russian History, Russian Faculty of Law in Prague, Russian Orthodoxy, Ivan the Terrible.

Написание русской истории в нацистской Германии: случай Виктора Владимировича Леонтовича (часть вторая)

\section{Г. Гамбург}

Для цитирования: Hamburg G. Writing Russian History in Nazi Germany: the Case of Viktor Vladimirovich Leontovitsch (Part Two) // Вестник Санкт-Петербургского университета. История. 2018. T. 63. Вып. 2. C. 572-596. https://doi.org/10.21638/11701/spbu02.2018.215

Кто знал видного историка В. В. Леонтовича до издания в 1957 г. его знаменитой «Истории либерализма в России»? Впрочем, «знаменитой» книга стала гораздо позже, ведь на русский язык она была переведена только в 1980 г., а на английский и того позже через 32 года! Но и тут возник своего рода казус, поскольку знаменитая книга, став таковой, не расширила знаний об авторе - ни в ученом мире, ни в широких кругах

Gary Hamburg — PhD, Professor, Claremont McKenna College, 888 Columbia Avenue, Claremont, California, USA, 91711; gary.hamburg@claremontmckenna.edu

Гари Гамбург - PhD, проф., колледж Клермонт Маккенна, 888, Коламбия авеню, Клермонт, Калифорния, США, 91711; gary.hamburg@claremontmckenna.edu

(c) Санкт-Петербургский государственный университет, 2018 
читающей публики. Никто не взялся проанализировать процесс становления Леонтовича как личности и ученого, никто не посвятил этому серьезных научных трудов. Это тем более обидно, что Леонтович - один из крупных мыслителей российского и украинского зарубежья, историк, правовед, создавший интересные и ценные труды по истории и истории права. Автор статьи, опираясь на широкий круг опубликованных и архивных источников, восполняет этот досадный пробел. Читатель узнает о детстве и юности ученого, его развитии во время учебы в российской гимназии и на Русском юридическом факультете в Праге, в Париже в Свято-Троицком православном теологическом институте, о работе в этом же институте, переезде в Германию, об отношении к православной религии и нацизму. Леонтович не принял нацизм, критиковал его лозунги. В статье проанализированы работы ученого времени его пребывания в Германии, которые охватывали широчайший круг проблем: историю русского церковного права в сравнении с протестантизмом, французское право, становление современного государства. Значительное внимание уделено анализу интересной работы Леонтовича, посвященной правлению Ивана Грозного, а также взаимовлиянию Леонтовича и ряда других крупных ученых русского и украинского зарубежья, таких как Александр Макаров, Дмитрий Чижевский и Федор Степун. Портрет Леонтовича - это портрет целого поколения российской эмиграции, поколения, отвергшего диктатуру и в советской, и в нацистской форме, непонятого и обретшего лишь одиночество в ряду других поколений.

Ключевые слова: Леонтович, русская история, Русский юридический факультет, Русское православие, нацизм.

\section{III}

Before leaving the question of Leontovitsch's attitude toward National Socialism, let us reflect on two additional aspects of his situation: his personal disposition and his intellectual network. Although Leontovitsch came from a politically engaged family and had been formed intellectually in the conservative-liberal wing of the Russian emigration, he portrayed himself as an apolitical man. In adolescence, he made friends with such different types that he "could not make of them a single circle or group". He focused so intently on reading books that he "never was a regular reader of newspapers, ... [and] didn't read them at all for weeks on end"1. In Germany, he kept to a tight circle of trusted friends and avoided an active social life. At home, he kept quiet about his life in Russia before emigrating and spoke only guardedly about contemporary politics ${ }^{2}$. In public, Leontovitsch apparently wore a "mask" behind which he hid his thoughts about politics; donning such a mask was a virtual necessity for outsiders under the National Socialists. Perhaps wearing a "mask" was also a function of Leontovitsch's commitment to the Russian liberal tradition, which strongly distinguished the public sphere from the private sphere. Incidentally, Leontovitsch's apolitical conduct had little in common with Thomas Mann's famous

${ }^{1} \mathrm{He}$ added that sometimes he indulged in "binge-reading": "I sometimes dove into several newspapers in various languages." [Leontovitsch], Lebensbeschreibung (unpublished, undated document, from private papers of the Leontovitsch family). P. 1. I am indebted to Parmen Leontovitsch and Julia Oswalt for a digital copy of this document.

${ }^{2}$ On the Leontovitsch's social situation in Berlin and on Leontovitsch's avoidance of inviting guests in groups, see: Oswald J. Zwischen den Welten 1934-1953 // Kriegskindheit und Nachkriegsjugend in zwei Welten. Deutsche und Russen blicken zurück / Hrsg. von B. Bonwetsch. Essen, 2009. S. 34-35. Oswalt noted that in 1944, when girls of her age joined the Bund Deutscher Mädel, her parents avoided telling her that involvement in the female equivalent of the Hitler Youth movement was "daft" (Ibid. P. 37). 
self-conception as "unpolitical man," for Mann opposed the bourgeois, aesthetic realm to the political realm. He rejected political terms such as "freedom," "legality," and "truth" as unhelpful abstractions ${ }^{3}$.

Even though Leontovitsch conducted himself circumspectly, he could not have survived as a professional jurist or as an intellectual without friends. His loose network of associates included at least three key figures: the legal scholar Aleksandr Nikolaevich Makarov; the linguist, philosopher and literary critic Dmitrii Ivanovich Chizhevskii (Tschizewskij); and the belletrist and philosopher Fedor Avgustovich Stepun.

Leontovitsch's position at the Kaiser-Wilhelm-Institut für ausländisches und internationales Privatrecht might have been unsustainable if he had lacked the patronage of Aleksandr Nikolaevich Makarov - an expert on provisions of Soviet law relevant to international private law ${ }^{4}$. Indeed, Makarov was probably the person chiefly responsible for securing Leontovitsch's position at the Institute ${ }^{5}$. Makarov had received his training at St. Petersburg University before the war, and from 1914 to 1919 had served there as docent in the Law Faculty. In 1919, he was appointed professor of international law at Petrograd University - a post he retained until the authorities removed him in 1923, for failing to adopt the proper class-perspective in his book Osnovnye nachala mezhdunarodnogo chastnogo prava. Makarov's approach in the book was to analyze conflicts between Soviet law and international legal norms as examples within a larger paradigm of conflicts between national statutes and international norms: to the Soviet authorities, this "comparative" approach was per se objectionable, because it treated Soviet law as a new iteration of an older pattern ${ }^{6}$. Makarov emigrated from the USSR to Germany in 1925 and established himself at the Kaiser-Wilhelm Institute in 1928. His European reputation rested largely on an extraordinary compilation of sources on private international law from sixty countries ${ }^{7}$. By 1937, when Leontovitsch joined the Kaiser-Wilhelm Institute, Makarov was likely the most prominent legal scholar in the Russian diaspora. As a committed internationalist hostile to national particularism, he was a silent opponent of National Socialism. Makarov may, therefore, have been the only person at the Institute whom Leontovitsch trusted. According to Oswalt, the Leontovitschs socialized with Makarov and his family throughout the war.

Dmitrii Chizhevskii was one of the century's great literary critics, and easily the most prolific in the Russian diaspora9. Like Leontovitsch, he came from a noble family with

${ }^{3}$ See: Mann T. Betrachtungen eines Unpolitischen. Berlin, 1918.

4 See: Makarov A. N.: 1) Liga natsii. Petrograd, 1922; 2) Osnovnye nachala mezhdunarodnogo chastnogo prava. Moscow, 1924; Makarov A. N. Osnovnye nachala mezhdunarodnogo chastnogo prava. Moscow, 2005; 3) Pravovoe polozhenie inostrantsev v SSSR. Moscow, 1924; 4) Das russische Zwischenprivatrecht (internationales Privatrecht). Berlin, 1926; Makarov A. N., Loewenfeld W. Das internationale Privatrecht der europäischen und auseuropäischen Staaten. Berlin, 1929.

${ }^{5}$ Oswalt J. Zwischen den Welten... S. 35.

6 The table of contents of Makarov's book can be read at: Iuridicheskaia nauchnaia biblioteka izdatel'stvo "SPARK". URL: http://www.lawlibrary.ru/izdanie10899.html (accessed 16.01.2015).

7 Makarov A. N., Loewenfeld W. Das internationale Privatrecht... Makarov was responsible for gathering and systematizing the legal materials for this book.

8 Oswalt J. Zwischen den Welten... P. 35.

9 For a bibliography of his works, see: Bibliografiia pechatnykh trudov D. I. Chizhevskogo 1912-1994 // Chizhevskii D. I. Izbrannoe. In 3 vols. Vol. I. Materialy k biografii (1894-1977). Moscow, 2007. P.772-807. Chizhevskii's publications numbered over one thousand items; many drafts of articles he wrote just before or during the war remain unpublished. 
property in Ukraine, was educated in Kiev, and was forced to emigrate during the Russian civil war. Again, like Leontovitsch, he spent a decade in Prague (from 1923 to 1932), although Leontovitsch was a student there while Chizhevskii served as professor at the Ukrainian Pedagogical Institute. Like Leontovitsch, Chizhevskii took an academic position in Germany, in his case at the University of Halle, where from 1932 to 1945 he taught Slavic studies, philosophy, various Indo-European languages and the history of the Church ${ }^{10}$. Leontovitsch and Chizhevskii shared an interest in Russian intellectual history: in 1935, Chizhevskii delivered a lecture course on "Ideological Currents in Russia in the XVIII and XIX Centuries" 11 . They also shared an interest in Church history: Leontovitsch focused on the Church's formation and early history in Byzantium, Chizhevskii on religious dimensions of early Russian literature, on Russian saints' lives, on religion in Czech literature, and especially on the seventeenth-century Czech educational reformer Jan Amos Comenius whose "lost" work he found and edited 12 .

In his youth, Chizhevskii had been a committed Marxist: from 1912 to 1924, he belonged to the Menshevik faction of the Russian Social-Democrats, and after 1921 he associated himself with the moderate wing of German Social-Democracy ${ }^{13}$. Around 1926, he experienced a religious conversion. He returned to Russian Orthodoxy not as the one true Church, but instead he embraced Orthodoxy alongside "the great Western confessions"14. His sympathy for both Eastern and Western Christianity made him an ecumenist not unlike Leontovitsch.

Like Leontovitsch's posts in Berlin, Chizhevskii's academic position in Halle was precarious. The Halle University authorities had promised him a chair in 1932, but they reneged on this promise the next year, when the Nazis came to power. For them it was risky to install an émigré Slav in a permanent post, but their main hesitation in appointing Chizhevskii had to do with his Jewish wife, Lidiia Marshak. The Halle chief of police asked the university to dismiss Chizhevskii from the faculty, but the dean defied the local police by keeping Chizhevskii as an adjunct lecturer ${ }^{15}$.

From various sources, we know that Chizhevskii opposed National Socialism. In his 1945 autobiography, he noted that much of his scholarship on philosophical and political problems "showed the absurdity of the National-Socialist worldview." During the 1930s, he offered "material assistance" to several Czech and Polish Jews; during the war, he sent books and items of necessity to Russian and Polish prisoners of war. He resented the Gestapo for ordering him to stay in Halle during the $\operatorname{war}^{16}$. In this same autobiography, he

10 Chizhevskii D. I. Avtobiografiia (1933), Avtobiografiia (1934), Avtobiografiia (1941) // Ibid. P. 45-47.

11 Ibid. P. 47.

12 On Chizhevskii's contributions to Comenius' studies, see: Korthaase W. Chto proiskhodilo s glavnym sochineniem Komenskogo 'Consultatio catholica’ s 1934 po 1945 god // Chizhevskii D. I. Izbrannoe. V trekh... P.316-327; Patocka J. O komeniologicheskikh trudakh Dmitriia Chizhevskogo // Ibid... P. 328-336.

13 Chizhevskii D.I. Tvorcheskaia avtobiografiia. Iiul' 1945 goda // Chizhevskii D.I. Izbrannoe... P. 51-52.

14 Ibid. P. 52.

15 Ibid. P.49. For another reference to Chizhevskii's difficult position, see: Berkefeld W. Malen'kii kruzhok v Galle // Chizhevskii D. I. Izbrannoe... P.309-315. - In his 1962 address to the Heidelberg Academy of Sciences, Chizhevskii mentioned that, at Halle, "I could expect dismissal at any moment." See: Chizhevskii D.I. Rech' po sluchaiu izbraniia deistvitel'nym chlenom Geidel'bergskoi Akademii Nauk (1962) // Ibid. P. 72.

${ }_{16}$ Chizhevskii D.I. Tvorcheskaia avtobiografiia. Iiul' 1945 goda // Ibid. P.50. During the war Chizhevskii was under orders not to leave the confines of the city. 
boasted that, among close friends from Freiburg, "not a single person became a National Socialist; moreover, many fought National Socialism from the time of its establishment."17 In a 1945 letter to Thomas Mann, Chizhevskii declared himself sympathetic to a large group of German intellectuals "who for twelve years said and did nothing that they might not have said or done without Hitler," although he conceded: "some of them perhaps keep silent, spoke softly and acted cautiously" in those years ${ }^{18}$. One of his student acquaintances from Halle recalled that, in 1941, when Germany invaded the Soviet Union, Chizhevskii "had no illusions about the catastrophic outcome for Germany"19.

Chizhevskii repudiated the Europe of his day for its national egoisms. He advocated the "overcoming of obstacles to mutual understanding and peace among peoples." $\mathrm{He}$ sought "ways to bring about the cultural alignment of European peoples," and proposed that the key to Europe's future lay in "the flowering of European scholarship" 20 . In his 1945 letter to Mann, Chizhevskii insisted that European culture could not cohere unless Germany's post-war isolation was overcome and unless the Germans recovered both their human dignity and sense of self-worth ${ }^{21}$. It is possible that Chizhevskii stayed in Germany during the war mainly because he had discovered in Comenius' lost work a template for a united Europe based on humanist values ${ }^{22}$.

According to Oswalt's memoirs, in 1943, the Leontovitschs stayed in Halle at Chizhevskii's apartment when they were seeking a place to live outside Berlin. She remembered that Chizhevskii advertised his non-German background by shouting to a student that he did not greet anyone by saying "Heil Hitler." According to Oswalt, Leontovitsch also stayed at Chizhevkii's apartment in winter 1944-1945 when he was lecturing in Ber$\operatorname{lin}^{23}$. In post-war correspondence with Semen Ludvigovich Frank, Chizhevskii noted that "among teachers [of Russian] there remain only Leontovitsch (as Privatdozent in Byzantine law) at Frankfurt, myself and Stepun. All the rest, including everyone sympathizing with the 'German national spring' have fled as 'refugees' and quite successfully hidden themselves in Switzerland"24.

Fedor Stepun was one of the most extraordinary figures of the Russian diaspora. A philosopher trained in Moscow and Heidelberg, he defended his doctoral dissertation in 1910 on the thought of Vladimir Solov'ev ${ }^{25}$. During the Great War, he served as an artillery officer in the Russian army - an experience he captured in a series of trenchant letters

${ }_{17}$ Chizhevskii studied philosophy in Freiberg in the early 1920s, just after his emigration from Ukraine. Chizhevskii D. I. Tvorcheskaia avtobiografiia. Iiul'... P. 51.

18 D. I. Chizhevskii - T. Mannu. Letter of 27 October 1945 // D. I. Chizhevskii. Izbrannoe... P. 173. On this letter, see: Korthaase W. Dmitrii Chizhevskii i rodina ego vybora Germaniia // Dmytro Čyževskyj, osobnost a dílo: sborník prŕspěvků z mezinárodní konference pořádané Slovanskou knihovnou při Národní knihovně ČR... 13. - 15. června 2002 v Praze / ed. by Z. Rachůnkova. Prague, 2004. P. 101-128.

${ }^{19}$ Berkefeld W. Malen'kii kruzhok... P. 315.

20 Chizhevskii D. I. Tvorcheskaia avtobiografiia. Iiul'... P. 56-57.

${ }^{21}$ D. I. Chizhevskii - T. Mannu... P. 175.

${ }^{22}$ Chizhevskii had discovered Comenius' great work, Consultatio catholica, in Halle in 1934 . He dedicated much time in the next decade to transcribing and editing this enormous manuscript of nearly four thousand pages. The editors of Materialy $k$ biografii, Vladimir Iantsen, Iryna Valiavko and Werner Korthaase, argue in their commentary that Chizhevskii's editorial work on, and search for, new Comenius manuscripts "were among the most important reasons that he stayed in Nazi Germany, at the risk of his life." See: Kommentarii // Chizhevskii D. I. Izbrannoe... P. 562.

${ }^{23}$ Oswalt J. Zwischen den Welten... P. 36.

${ }^{24}$ D. I. Chizhevkii - S. L. Franku, letter of 9 March 1947 // D. I. Chizhevskii. Izbrannoe... P. 185-186.

25 Stepun F. Wladimir Solowjew. Leipzig, 1910. 
written between September 1914 and May $1917^{26}$. In them, Stepun made clear his opposition to a brutal conflict lacking a metaphysical purpose, a conflict that amounted to the forced slaughter of millions of men at the bidding of state authorities ${ }^{27}$. Although a man of the left, Stepun claimed never to have been a revolutionary. Still, he received news of the February revolution "joyously," seeing in it the possibility of an exit from disastrous war $^{28}$.

In April 1917, Stepun became a member of the All-Russia Soviet of Workers', Peasants' and Soldiers' Deputies, a body he described as "a formless and unwieldy institution" 29 , whose members "interested themselves solely in ideological flights of fancy" 30 . Observing from the Soviet the hapless Provisional Government, he decided that the incompetence of both institutions was only preparing the way for Russia's military defeat and ultimate disintegration. Furthermore, he feared that February 1917's optimism would propel to power the leader of the extreme left, Vladimir Il'ich Lenin, whom he remembered as "archaically monumental," calculating and self-possessed, a man who, "thinking about the revolution in utter solitude, nevertheless lived by mass psychology"31. To set the revolution on a constructive path, Stepun accepted in June an invitation to serve in the war ministry under Aleksandr Fedorovich Kerenskii, as head of the political department. For some months, Stepun became a kind of official propagandist whose editorials in the newspaper Invalid did little to improve the army's morale or to stabilize Russia; instead, holding the position led Stepun by late summer 1917 into making a short-lived, ill-starred alliance with Kerenskii, General Lavr Georg'evich Kornilov and commissar Boris Viktorovich Savinkov ${ }^{32}$.

Stepun's political experiences in 1917 - he was one of few creative intellectuals to have served both in the Soviet and in a government ministry - haunted him for the rest of his life. At first, after the Bolshevik revolution, he sought to put matters rights by simultaneously collaborating with and criticizing Soviet cultural institutions. In 1918-1919, Stepun worked in Moscow's "Theater of Revolution," where he tried to re-introduce into the dramatic repertoire tragic plays, such as Sophocles' Oedipus Rex, and to avoid contemporary plays full of Marxist agitation. In 1920, at a public gathering in Moscow's Malyi teatr, he portrayed the theater both as a means of writing history and as a cultural counterweight to governments in power - a view that some spectators took as an open challenge to the new regime. Stepun himself called the gathering "the last peaceful protest by Old Moscow against the communist party"33. In winter 1919-1920, he took part in Nikolai Nikolaevich Berdiaev's Free Academy of Russian Culture - a venue for the Russian intel-

26 The letters from 1914 to December 1916 appeared in censored form under a pseudonum, as: Lugin N.: 1) Iz pisem artillerista-praporshchika // Severnye zapiski. 1916. N.6. P.150-170; 2) Iz pisem artillerista-praporshchika // Severnye zapiski. 1916. N.7-8. P. 145-160; 3) Iz pisem artillerista-praporshchika // Severnye zapiski. 1916. N. 9. P. 9-23; 4) Iz pisem artillerista-praporshchika // Severnye zapiski. 1916. N. 11. P. 108-120; 5) Iz pisem artillerista-praporshchika // Severnye zapiski. 1916. N. 12. P. 1-13. The full version of the letters was published in book form as N. Lugin [pseudonym of Fedor Stepun]: Stepun F. Iz pisem praporshchika-artillerista. Moscow, 1918. See also: Stepun F. Iz pisem praporshchika artillerista. Prague, 1926.

27 On Stepun's war letters, see: Hufen C. Fedor Stepun. Ein politischer Intellektueller aus Russland in Europa. Die Jahre 1884-1945. Berlin, 2001. S. 70-73.

28 See: Stepun F. Byvshee i nesbyvsheesia. Moscow; St. Petersburg, 1995. P.311-312.

29 Ibid. P. 337.

30 Ibid. P. 341.

31 Ibid. P. 345, 358.

32 On Stepun's "governmental carrier" see: Hufen C. Fedor Stepun... S. 80-85.

33 Ibid. S. 94. 
lectual opposition to develop its views. Friendship with Berdiaev and other philosophical Idealists, along with Stepun's role in the 1922 publication Oswald Spengler and the Decline of Europe, resulted in his expulsion from Soviet Russia in summer $1922^{34}$.

In emigration, between 1922 and 1928, Stepun wrote a series of essays under the title, Thoughts on Russia [Mysli o Rossii], for the journal Sovremennye zapiski ${ }^{35}$. The essays constituted reflections on the Russian revolution from cultural, historical and philosophical perspectives. The essays equated Bolshevism with chaos and destructiveness but also dismissed the White movement for its retrograde monarchism. Stepun argued, following Dostoevskii's premise of universal responsibility, that politically active Russians of all stripes bore collective guilt for the revolution ${ }^{36}$. He lamented Russians' lack of patriotism, their failure to generate ethically and legally defensible notions of property, and their hostility to genuine democracy. He called for an affirmation of personhood based on belief in God, human dignity and the rootedness of individuals in the community ${ }^{37}$. $\mathrm{He}$ interpreted literature in the civil war period as a subversive force, as a venue in which concrete ethics confronted an abstract, life-denying ideology ${ }^{38}$. In a 1925 essay distinguishing between the socialist idea and Bolshevik ideology, Stepun portrayed Lenin as a dogmatic and fanatical ideologue, who combined Marx's commitment to centralization with the anarchist Mikhail Bakunin's lust for destruction ${ }^{39}$. Stepun's Thoughts on Russia stimulated Leontovitsch investigation into the groundedness of the revolution in Russian culture, and also contributed to Leontovitsch's curiosity about the lack of property-consciousness among Russian peasants. Stepun's 1934 book Das Antlitz Russlands und das Gesicht der Revolution [The Visage of Russia and Face of the Revolution], based on Thoughts on Russia, appeared just as Leontovitsch finished his master's degree in Prague and re-located to Berlin ${ }^{40}$.

As we have seen, Stepun commanded wide interest in the Russian diaspora for his range of political experiences and for the acuteness of his observations about Russian society before and after 1917. But in the early 1930s, he also earned a reputation as a perceptive analyst of German society and politics. This reputation grew out of his work at the Technische Hochschule in Dresden, where he taught sociology from 1925 to 1937. Although some of his early Dresden lectures dealt with elementary sociological subjects (he taught sociological method and a course called "Sociology of Large Cities") and with problems raised by the Russian revolution (he taught a course called "Fundamental Problems of the Revolution," and another one, on the relationship between Bolshevik ideology and social practice), in the late 1920s he started to explore German sociology and the sociological problem of masses and leadership. In the 1930s, he offered lectures on cultural sociology in contemporary life, on German social and political theory, and, in 1936, on

${ }^{34}$ For an overview of these events, see: Ibid. P. 85-99. For the essay on Spengler, see: Stepun F. Osval'd Shpengler i Zakat Evropy // Osval'd Shpengler i Zakat Evropy / eds N.A.Berdiaev, J.M. Bukshpan, F. A. Stepun, S. L. Frank. Moscow, 1922. P. 5-33.

${ }_{35}$ For an authoritative discussion of these essays, see: Hufen C. Fedor Stepun... S. 165-186, 220-236.

36 See: Stepun F. Mysli o Rossii // Sovremennye zapiski. 1923. Vol. XV. P. 281-296.

37 Ibid. P. 299.

38 Ibid. P. 342-371.

39 Ibid. P. 350, 359.

40 Stepun F. Das Antlitz Russlands und das Gesicht der Revolution. Bern; Leipzig, 1934; see also the English version: Stepun F. The Russian Soul and the Revolution translated by Erminie Huntress. New York; London, 1935. 
"Tribe [Volk], Race and Culture"41. Stepun's Dresden studies gave him material for sophisticated essays on National Socialism as a social and political phenomenon.

Between 1930 and 1932, Stepun published a series of articles on German politics and National Socialism under the title Letters from Germany [Pis'ma iz Germanii] ${ }^{42}$. In 1933, he added a powerful article on Hitler's ascent to the office of Reichskanzler ${ }^{43}$, and in 1933-1924, a programmatic article upholding his own Christian politics as an antidote to National Socialism ${ }^{44}$. These articles, widely read in the Russian diaspora, cemented his reputation as an anti-Bolshevik and anti-Nazi theorist.

In his 1932 article on the German presidential elections, Stepun referred to the "battle of ideas" and to the "militarization" of political programs in Germany ${ }^{45}$. He noted that the National Socialists, by their "irresponsible demagoguery," had managed to "hypnotize" much of the German public ${ }^{46}$. However, he cited evidence that, beneath the public furor over politics, there ran deeper currents: the confused attachment of conservative Christians to Karl Barth's mistaken idea that political engagement of any sort requires an "unclean conscience" ${ }^{77}$; popular curiosity about the Russian revolution and popular hunger for a revolution in Germany ${ }^{48}$; the political incompetence of Germany communists ${ }^{49}$; the incoherence of the National Socialist movement, its reliance on protesting the Treaty of Versailles, its failure to frame a positive program, and its bizarre fabrication of Ersatz Christianity to serve as a political slogan ${ }^{50}$. Stepun reported listening to an unimpressive speech by Adolph Hitler at a Nazi party rally. He noted that, although Hitler had "said nothing," faith in him had become a kind of "psychosis that will not quickly dissipate"51.

In his 1933 essay on Hitler's January selection as chancellor and on the July arrest of Social-Democratic leaders in Prussia, Stepun spoke of "a devastating blow to democracy dealt by the National Socialists" 52 . He complained that Hitler had "disarmed and destroyed democracy by democratic methods, by using the rules of a rule-of-law state" 53 . Stepun laid considerable blame for this outcome on the "intellectual parochialism" of Social Democrats, a parochialism he related to their lack of religiosity, to their lack of patriotism, and to their "bourgeois outlook" ${ }^{4}$. He now argued that the National Socialists had seized the banner of revolution from the Social Democrats, a seizure of political initiative he interpreted as "the victory of revolutionary evil over revolutionary good." He predicted that now Germany would not move toward a new medieval age, but rather toward "some

${ }^{41}$ See: Hufen C. Fedor Stepun... S. 573-574.

42 See: Luganov N.: 1) Pis'mo iz Germanii (Formy nemetskogo sovetofil'stva) // Sovremennye zapiski. 1930. Vol. XLIV.P. 448-463; 2) Pis'ma iz Germanii (Natsional' sotsialisty) // Sovremennye zapiski. 1934. Vol. XLV. P. 446-474; 3) Pis'ma iz Germanii (vokrug vyborov presidenta respubliki) // Sovremennye zapiski. 1932. Vol.XLIX. P. 402-421. Nikolai Luganov is a pseudonym for Fedor Stepun.

43 [Stepun F.] Redaktsiia. Germaniia prosnulas' // Novyi grad. 1933. Vol. VII. P. 3-24.

44 Stepun F.: 1) Khristianstvo i politika // Sovremennye zapiski. 1933. Vol. LIII. P. 335-352; 2) Khristianstvo i politika // Sovremennye zapiski. 1934. Vol. LV.P.308-325.

45 Stepun F. Pis'ma iz Germanii... P. 402.

46 Ibid. P. 403.

47 Ibid. P. 408.

48 Ibid. P. 408-410.

49 Ibid. P. 411-413.

50 Ibid. P. 413-414.

51 Ibid. P. 418.

52 Stepun F. Germaniia prosnulas'... P. 3.

${ }^{53}$ Ibid. P. 4.

${ }^{54}$ Ibid. P. 5. 
sort of new barbarism"55. Stepun linked the coming disaster to the Nazis' successful manipulation of mass psychology through the radio and to the Nazis' freakishly clear sense of Germans' "collective spirit" 56 . He hoped that the Nazi hold on Germans would eventually weaken, and indeed, he anticipated it must: the Nazis' political pose was a "betrayal of truth," a "betrayal of freedom," a betrayal of Christianity and of the German nation ${ }^{57}$. He called National Socialism a method of "Bolshevizing the soul of national Germany," while using opposition to Bolshevism as a "national poison"58. Yet he thought the Nazis "more terrible than Bolshevism," because they hid their destructive program behind seductive slogans. He feared that, in the end, National Socialism would mean nothing other than concentration camps and self-destructive racism ${ }^{59}$.

In a private letter to the theologian Paul Tillich in 1934, Stepun complained about "the claustrophobic atmosphere" in Germany, where he could speak candidly with fewer than "eight to ten people." He reported the killing of the Röhm faction of the NSDAP in June 1934 as evidence that Hitler had turned away from a revolution against capitalism, and that the Nazi authorities were now trying to cement "an alliance between the Reichswehr and big capital." He told Tillich that the best students in Dresden were listening carefully to lectures on political theory concerning the thought of Vilfredo Pareto, Georges Sorel, and Carl Schmitt; however, he admitted that many students still gravitated toward National Socialism, just as two decades earlier, Russian students had joined the Bolsheviks. Stepun was so upset with the political situation in Dresden that he pulled aside a student leader and spoke to him candidly about the dangers Nazism presented to freedom of conscience and about "anti-Semitism as a sin of the Christian world" 60 .

In March 1935, Stepun wrote Tillich that he had now decided to join the fight of the Confessing Church against National Socialism and against the "philistinism" of capitalism and socialism. He sought to make contacts between "religious (Christian), freedom-loving (creative) socialists of the world to do battle against the demonism and philistinism engulfing us." Concretely, he strove to link "genuine religious socialism" of sort represented by his journal Novyi grad, and the "religious secularism" represented by Jacques Maritain $^{61}$. Although Stepun enjoyed a certain freedom of maneuver - he claimed he could "speak freely with decent people" - he noted that by 1935 "Jews have been relatively isolated"62.

The difficult political and religious climate fostered by the National Socialists' seizure of power constituted the background for Stepun's religious-political program of 19331934. In a two-part article, he argued that both the Bolsheviks and the Nazis were waging a social war against Christianity — the Bolsheviks by shooting priests and closing churches, and the Nazis by fostering a surrogate faith, which he called a "brown-shirted soldiers' Christianity" 63 . In view of this dual assault, he asserted, neither Roman Catholic nor Prot-

55 Ibid. P. 10.

56 Ibid. P. 13-14.

57 Ibid. P. 17-18.

58 Ibid. P. 19.

59 Ibid. P. 20-21.

${ }^{60}$ Perepiska Fedora Stepuna i Paulia Tillikha. 1. Tsirkular (Rundbrief) Fedor Stepuna [1934] // Fedor Stepun. Pis'ma / ed by V. K. Kantor. Moscow, 2013. P. 200-202.

${ }_{61}$ Perepiska Fedora Stepuna i Paulia Tillikha. 2. Pis'mo 27 marta 1935 g. // Ibid. P. 211, 213.

62 Ibid. P. 216.

63 Stepun F. Khristianstvo i politika // Sovremennye zapiski. 1933. Vol. LIII. P. 335-352. 
estant attitudes toward Christian politics were sensible. Catholics had oriented themselves toward Aquinas' theocracy, but the practical result of their thinking had been a "profound conservatism" of the sort that had led the head of the Center Party, Heinrich Brüning, to make a tactical alliance with Hitler ${ }^{64}$. Most Protestants, with their conviction that all worldly authority comes from God, had proven to be political opportunists willing to support National Socialism ${ }^{65}$. Stepun saw in the Orthodox Church a better historical path, a proper model for the political order. He admired the sixteenth-century Volga elders for their blunt criticisms of Muscovite political tyranny and for their quiet refusal to sanction the violent suppression of alleged heretics ${ }^{66}$. He praised Metropolitan Filipp for opposing Ivan IV's oprichnina, Vladimir Solov'ev for opposing the execution of Tsar Aleksandr II's assassins, and Patriarch Tikhon for prophetically criticizing the Bolsheviks ${ }^{67}$. Stepun saw the Optina Pustin' monastery's effort to engage the world without becoming part of it as a way forward for a Church seeking autonomy from the state, for preaching righteousness in politics, and for retaining a "mystical link with popular/national culture"68. Stepun refused to accept Carl Schmitt's reduction of politics to hatred of the "enemy," even if contemporary Europe was full of precisely such hatred ${ }^{69}$, and even if most Christians followed Schmitt's idea that Christian belief need not entail pacifism ${ }^{70}$. Instead, Stepun demanded that Christians support a "free spiritual life," that they oppose social oppression, and that they reject the temptation of self-righteousness in politics ${ }^{71}$.

In Stepun's opinion, Christianity is a "profoundly peace-loving and definitely anti-nationalistic religion," yet it permits Christians to shed blood in self-defense and therefore cannot be considered pacifistic ${ }^{72}$. Furthermore, as Stepun defined it, Christianity is a belief system that recognizes both evil's existence in the world and the imperative to struggle against it. In this sense, he thought, Christians are realists. Because fighting evil often requires taking the lives of malefactors, and because killing is an act Christians regard as sinful, Stepun described the Christian faith as "tragic". In pondering the tragic nature of Christianity, he argued that the sinfulness involved in the struggle against evil and in the Christian duty to take moral responsibility for evil, wherever it occurs, forces Christians to transform "inhuman evil into human $\sin ^{73}$. Stepun wanted Christians to grasp that state violence in wartime, like state executions of criminals in peacetime, can never be considered good. Instead, state violence must be classified as tragically sinful.

Stepun rejected as a pernicious lie the notion that Christians should ignore their duty to protest in the face of actions or movements that seemed historically "inevitable." He did not dispute that recent events in Nazi Germany had unfolded in a manner that seemed to many Germans to be ineluctable, but he thought that, even if one granted the assumption that Germany had a certain "destiny" or "fate," Christians in Germany still could not

\footnotetext{
64 Ibid. P. 337.

65 Ibid. P. 338-340.

66 Ibid. P. 341-342.

67 Ibid. P. 342.

68 Ibid. P. 343.

69 Ibid. P. 344-346.

70 Ibid. P. 347-348.

71 Ibid. P. 349-352.

72 Ibid. Vol. LV. P. 308

73 Ibid. P. 310-311.
} 
escape responsibility for this fatum ${ }^{74}$. In the end, he held that Christians should "warn" the state against immoral acts and should protest against them, and thus should exercise a "powerless authority" [bezvlastnoe vlastvovanie] over the state ${ }^{75}$. His "program" therefore was ethical and "supra-political": it could not be translated into a set of political axioms, into a conventional political platform, or even into a conventional set of normative political behaviors ${ }^{76}$. In Stepun's opinion, it was perhaps a mistaken enterprise even to speak of "Christian politics," when the emphasis should instead be on the contingent ethical and political posture of individual Christians. He advocated this contingent, ethical approach to politics as a "healthy" antidote to political dogmatism and utopianism, to the "violent ideological tendency" of contemporary politics ${ }^{77}$.

In short, Stepun rejected the naive liberalism of the nineteenth century and the "ideocracy" of contemporary Europe (Bolshevism, Nazism, fascism). He upheld instead Christian "truth." He regarded the great Christian tradition as Europe's only hope, and the "small deeds" of individual Christians as the foundation for that hope. He did not deny the difficulties in overcoming Bolshevism, Nazism and fascism, but he nevertheless proclaimed: "All roads leading to truth travel the abyss's edge"78.

In June 1937, the Dresden authorities dismissed Stepun from the civil service and from his teaching post at the Technische Hochschule ${ }^{79}$. They also imposed upon him a prohibition on public lecturing and on publication ${ }^{80}$ that remained in force till the end of World War II.Stepun took advantage of his forced retirement to write memoirs of his activity in Russia before and during the revolution. During the war period, he became a political symbol in the Russian diaspora of opposition to the political evils of the twentieth century.

It is likely that in Prague in the 1920s, Leontovitsch read Stepun's Thoughts on Russia, and in the 1930s his Letters from Germany. Both those epistolary cycles appeared in the leading "fat" journal of the Russian emigration, Sovremennye zapiski, a journal in which many of Leontovitsch's teachers also published. Even if Leontovitsch had not followed the journal itself, he could not have avoided conversations among Russians about its contents. Starting in 1931, Stepun also published in the journal Novyi grad ${ }^{81}$. That journal's Christian philosophical orientation would have attracted Leontovitsch as a practicing Russian Orthodox and as a Church historian. Leontovitsch shared certain elements of Stepun's Christian outlook: his hostility to nationalism, his anti-utopianism, his moralism. Like Stepun, Leontovitsch opposed Bolshevism and National Socialism. Again, like Stepun, Leontovitsch saw recent Russian and Germany history as tragic. These points of symme-

${ }^{74}$ Ibid. P. 312.

75 Ibid. P. 314 .

76 Ibid. P. 315-316.

77 Ibid. P. 320

${ }^{78}$ Ibid. P. 325.

79 Hufen C. Fedor Stepun... S. 494.

${ }^{80}$ Ibid. P. 507.

81 Novyi grad appeared in Paris from 1931 to 1939, under the editorship of I. Bunakov [pseudonym for Il'ia Isidorovich Fondaminskii], Georgii Petrovich Fedotov and Stepun. The editorial board considered it a philosophical journal written from a Christian perspective. Fourteen issues were published. For a bibliography of articles published there, and in other major publication of writers in the Russian diaspora, see: L'Émigration russe. Revues et recueils, 1920-1980: index général des articles / éds T. L. Gladkova, T. A. Osorgina. Paris, 1988. 
try between Stepun and Leontovitsch bespeak either Stepun's influence on Leontovitsch, or certain "parallels" in their intellectual evolution from the early 1920s to the mid-1930s.

We do not know when Leontovitsch met Stepun. Their extant personal correspondence began in late summer 1944. In a letter dated 15 August of that year, Leontovitsch referred to a meeting with Stepun three months earlier (in May), and proposed a future meeting "continuing our dialogues" 82 . This remark suggests two possibilities: either a continuation of a personal relationship that began in May 1944, or continuation of dialogues that had commenced even before then. Leontovitsch's daughter Julia Oswalt recalled that Stepun visited her family several times after the war's end. She testified that Stepun wore "a much too large, broad-brimmed hat" and a "capacious coat" that "seemed to harbor his all-embracing thoughts." She described Stepun's relationship with Victor Leontovitsch as "not untroubled," but she also testified that the friendship was close enough for Leontovitsch to have borrowed money from Stepun ${ }^{83}$.

\section{IV}

Leontovitsch's main scholarly activity during the war was preparation of his Habilitationsschrift on the "legal revolution" wrought by Ivan the Terrible ${ }^{84}$. We do not know when Leontovitsch began thinking about Ivan as a historical figure, but a fragmentary autobiography suggests the process may have commenced well before 1917, when he sat for hours in grandfather Lesevich's library. "Among the [great] historical personalities," he wrote, "there were none to whom I felt particular attraction, but there were some whom I thought especially unattractive, such as Ivan the Terrible" 85 . Later, while in Paris preparing for his master's examination in Church history, Leontovitsch read widely on the history of the Orthodox Church in Muscovy and Ukraine ${ }^{86}$. Among the works on Ivan IV's relationship to the Church, which Leontovitsch studied, were Evgenii Evstignevich Golubinskii's history of the Russian Church ${ }^{87}$, Nikolai Fedorovich Kapterev's analysis of the Russian Church hierarchy ${ }^{88}$, and Ivan Mikhailovich Pokrovskii's study of Russian bishoprics $^{89}$. Leontovitsch also made a special study of the Stoglav, the 1551 Church council, so important in modifying Russian canon law. He focused on regulations governing Church courts, regulations that clarified the distinction between ecclesiastical and state

${ }^{82}$ Letter from Victor Leontovitsch to Fedor Stepun, 15 August 1944, 1. 2 // Beinecke Library. Fedor Stepun Papers. Series I. Correspondence: Leontovitsch, Victor 1944-1959. General Manuscripts 172. Box 20, folder 682. My gratitude to Yale University's Beinecke Library for scanning this correspondence, and to Parmen Leontovitsch and Julia Oswalt for permission to cite their father's letters.

83 Oswalt J. Zwischen den Welten... S. 41.

${ }^{84}$ See: Leontovitsch V. Die Rechtsumwälzung unter Iwan dem Schrecklichen und die Ideologie der russischen Selbstherrschaft. Stuttgart, 1946. The book was finished by 1944, and was presented to the Faculty of Philosophy at the Johann Wolfgang Göthe University in Frankfurt-am-Main in the winter semester of 1946-1947. The manuscript was published in 1946, 1947 and again in 1949.

${ }^{85}$ Leontovitsch $V$. Lebenbeschreibung... P. 1.

${ }^{86}$ Kopiia. Otchet o rabote (s 1-go iiulia 1930 po 1-oe maia 1931 g.), Viktora Vladimirovicha Leontovicha // Gosudarstvennyi arkhiv Rossiiskoi Fedratsii (GARF). F. 5765. Op. 1. Ed. khr. 4. L. 403-406.

87 Golubinskii E.E. Istoriia russkoi tserkvi. In 2 vols, 4 pts. Moscow, 1901-1911; Leontovitsch would have been interested in volume 2 .

${ }^{88}$ Kapterev N. F. Svetskie arkhereiskie chinovniki drevnei Rusi. Moscow, 1874.

89 Pokrovskii I. M. Russkie eparkhii v XVI-XVII vv., ikh otkrytie, sostav i predely: opyt tserkovno-istoricheskago, statisticheskago i geograficheskago izsledovaniia. Kazan’, 1897. 
jurisdictions ${ }^{90}$. In analyzing these scholarly works, Leontovitsch must have thought hard about Ivan IV's contribution to Russian law.

At any rate, Leontovitsch finished his thesis in 1944, then defended it in 1947. His book was probably inspired by the Boris Nikolaevich Chicherin's work on the transformation of Russia from a decentralized network of principalities and city-states under private law to a modern bureaucratic state governed by universally applicable statutory law ${ }^{91}$. Leontovitsch held that objective law before Ivan IV "lacked the significance it came to have in the modern age" 92 . Under the allodial princes, the normative demands on individuals were often contradictory, such that individuals understood law as the "sum" of conflicting demands, or rather as a set of incoherent customary expectations. During Ivan IV's absolutist regime, the importance of custom diminished, because individuals now began to experience "the dominance of objective law" mandated by an "unlimited government"93.

According to Leontovitsch, in the epoch preceding Ivan, the main sources of Russian law were: agreements negotiated by allodial princes, or between princes and urban assemblies $[\text { vecha }]^{94}$; directives by individual princes aimed at their subjects ${ }^{95}$; folk customs ${ }^{96}$; and religious beliefs ${ }^{97}$. Leontovitsch maintained that each of these normative sources had limitations: the effect of negotiated agreements usually did not extend beyond the signatories' jurisdictions; decrees had purely local significance; folkways and religious ideas conditioned popular behavior, but they did not constitute law per se. Leontovitsch agreed with Mikhail Aleksandrovich Diakonov that religious belief was an especially problematic source of law, since Orthodox Christians tended to link sovereign political authority not to political power under law but rather to the exercise of personal virtue ${ }^{98}$. Thus, before Ivan IV, Russian law had what Leontovitsch called a "subjective character": it was binding on individuals, or on local groups, or on the virtuous, but it lacked the "objective character" of universally enforceable statutes. Under Ivan IV, an "undivided sovereign" issued laws binding on all subjects. Ivan therefore established in Muscovy an "objective legal order" $"$.

According to Leontovitsch, Ivan IV considered it an absolute imperative for Muscovites to obey him: no "subjective" rule, no subjective impulse could stand as obstacle to this duty. Indeed, Ivan thought, God alone stood between tsar and his subjects ${ }^{100}$. Nor did Ivan regard subjects' obedience to the tsar as a personal matter: in his thinking, obedience flowed from sovereignty. Ivan recognized only one exception to the duty to obey -

${ }^{90}$ Leontovitsch took a seminar from Anton Vladimirovich Kartashev on the Muscovite court system as outlined in chapters 67-69 of the Stoglav. As background, he read Vladimirovskii-Budanov M. F. Obzor istorii russkago prava. St. Petersburg; Kiev, 1888, and Beliaev I. D. Lektsii po istorii russkago zakonodatel'stva. Moscow, 1879, and Father Dmitrii (Stefanovich)'s dissertation: Stefanovich D. O Stoglave: Ego proiskhozhdenie, redaktsii i sostav: k istorii pamiatnikov drevnerusskago tserkovnago prava. St. Petersburg, 1909.

${ }^{91}$ See: Chicherin B. N. Oblastnye uchrezhdeniia Rossii v XVII-m veke. Moscow, 1856.

${ }_{92}$ Leontovitsch V. V. Die Rechtsumwälzung... S. 8-9.

${ }^{93}$ Ibid. S. 10.

94 Ibid. S. 11.

95 Ibid. S. 13-15.

96 Ibid. S. 16-17.

97 Ibid. S. 17-20.

98 Ibid. S. 21-22.

${ }_{99}$ Ibid. S. 22. - Here Leontovitsch disagreed with Chicherin, who had treated Peter the Great as the great legal system-maker.

100 Ibid. S. 26. 
namely, a case where the tsar had violated the Orthodox faith. But because Ivan thought of himself as acting consistently with Orthodoxy in all circumstances, there could be no practical justification for Muscovites to resist his will ${ }^{101}$ : the tsar did not acknowledge the legitimacy of any political authority in Muscovy other than himself ${ }^{102}$. Indeed, according to Ivan, only the tsar had the right to enforce statutory law, for God had given that right exclusively to him ${ }^{103}$ and with the duty to enforce law came the responsibility to fight godlessness in the realm ${ }^{104}$.

According to Leontovitsch, Ivan discussed the tsar's absolute sovereignty against the background of Muscovy's failure to prosper under divided aristocratic government ${ }^{105}$. In fact, he associated aristocratic rule with "fratricidal conflicts" 106 . Ivan also asserted that, as the case of Poland had demonstrated, divided government is inferior to autocracy. The tsar rejected government by priests, citing the fall of biblical Israel and of Orthodox Byzantium as examples of ruinous clerical rule ${ }^{107}$. According to Leontovitsch, Ivan conceded that priests perform important services in Orthodox realms, but Ivan warned against confusing priestly duties with the tsar's responsibility to act as principal defender of the faith through enforcement of the laws and through prohibitions on evil conduct ${ }^{108}$.

Ivan justified his authority as tsar partly by appealing to Orthodox Christian teaching concerning royal power, yet his reference to Christian teaching had led historians of Russian politics, such as Diakonov and Fedotov, to wonder whether Ivan had departed from Orthodox teaching. Diakonov had contended that Ivan had introduced "nothing new to this [Christian] theory [of the state]," whereas Fedotov had classified Ivan's political theory as a clear deviation from Orthodoxy ${ }^{109}$. In this dispute, Leontovitsch sided with Diakonov against Fedotov. According to Leontovitsch, the main disagreement between Ivan and Metropolitan Filipp over the exercise of royal authority focused on the oprichnina. Filipp disputed the tsar's ethical choice in using the oprichniki to destroy the tsar's imagined opponents but not the royal prerogative to establish such an institutional entity ${ }^{110}$.

Leontovitsch also disagreed with Fedotov's assessment of Prince Andrei Kurbskii namely, with Fedotov's view that Kurbskii had departed from typical Muscovite thinking about the state. According to Leontovitsch, Kurbskii upheld the Muscovite view of the realm as "the homeland of Orthodox Christianity," and of the tsar as religious leader charged with the care of Muscovites' souls. Kurbskii criticized Ivan for failing to defend the Orthodox realm, for acting as an "inner enemy" of the Church, and for violating good conscience - that is, for failing to act as loyal Muscovites expected a just ruler to behave ${ }^{111}$. In Leontovitsch's opinion, "Kurbskii represented the same ideology as Tsar Ivan and as most other thinkers of the age." The difference between Ivan and Kurbskii was that the prince concentrated not on the tsar's prerogatives as ruler, but rather on Ivan's fail-

\footnotetext{
101 Ibid. S. 28-29.

102 Ibid. S. 29.

103 Ibid. S. 31-32.

104 Ibid. S. 35.

105 Ibid. S. 36-37.

106 Ibid. S. 37.

107 Ibid. S. 38.

108 Ibid. S. 40-41.

109 Ibid. S. 44-46.

110 Ibid. S. 49-51.

111 Ibid. S. 51-56.
} 
ure to fulfill his royal duties ${ }^{112}$. According to Kurbskii, Ivan should have heeded his wise counselors" advice, but did not do so ${ }^{113}$; the tsar had also failed in his duty to try disgraced advisors, including those suspected of treason, according to established rules and taking into account their status as high priests and as members of the aristocracy ${ }^{114}$; neither had the tsar respected the property of Russian aristocrats ${ }^{115}$. However, according to Leontovitsch, Kurbskii was well aware that the tsar had no legal obligation to heed counselors' advice, no legal obligation to try disgraced advisors according to customary methods, and no enforceable legal duty to respect aristocrats' property.

Leontovitsch maintained that the ideology upheld by Ivan and the tsar's chief critics (Metropolitan Filipp, Prince Kurbskii), was rooted in the all-encompassing thinking of Iosif Volotskii, who had "left to [Muscovite] subjects no autonomy, no sphere of personal rights"116. According to Leontovitsch, Iosif's central teaching - that royal power comes from God - probably reached Ivan in early childhood, most likely from the lips of his father Grand Duke Vasilii ${ }^{117}$. Leontovitsch called this ideology "theocratic absolutism"118.

In chapter three of his book, Leontovitsch addressed the debate between those historians who had attributed the oprichnina to Ivan's irrationality or "madness," and those scholars who had treated the oprichnina as a response to changing historical conditions. Leontovitsch argued that Ivan was a political "rationalist," that the tsar's political theory and state system were based on a series of deductions from the "ideology" of theocratic absolutism, and thus that the terror imposed during the oprichnina flowed from the tsar's political principles. Leontovitsch did not deny that, when Ivan ordered the death of political opponents, the tsar acted "with cold heart," or even sadistically; however, the historian insisted that "an ideological justification must rest at the heart of any system of terror, for, without an ideological underpinning, a system of terror - a planned, prolonged application of terror aimed at entire groups in the population - would be unthinkable"119. Of course, Ivan's psychological make-up - his childhood hatred of the boyars, his sadistic impulses - played a role in initiating and executing the terror ${ }^{120}$, but more important was the link between this psychology and the tsar's ideological assumptions. The tsar imagined Muscovy as an "ideal kingdom" 121 , and pictured active and passive opponents of this ideal kingdom as "adversaries of righteousness"122.

In sketching the connection between terror and ideology, Leontovitsch admitted the influence of Vasilii Osipovich Kliuchevskii's Kurs russkoi istoriii, the second volume of which discussed the oprichnina by linking Ivan's psyche and youthful political outlook ${ }^{123}$. However, the most striking influence on Leontovitsch seems to have been volume five of Hippolyte Taine's Les origines de la France contemporaine, which, according to Leontovitsch, attempted to derive the Jacobins' psychology from their radical political views,

\footnotetext{
112 Ibid. S. 55-56.

113 Ibid. S. 56-58.

114 Ibid. S. 58-63.

115 Ibid. S. 63-64.

116 Ibid. S. 66.

117 Ibid. S. 68-70.

118 Ibid. S. 70.

119 Ibid. S. 79-80.

120 Ibid. S. 80.

121 Ibid. S. 81-82.

122 Ibid. S. 82-83.

123 Ibid. S. 72-85
} 
not the reverse ${ }^{124}$. According to Taine, the Jacobins had identified themselves with virtue and had asserted that virtue cannot be opposed "without crime"; in Taine's opinion, the Jacobins therefore took it upon themselves to suppress unvirtuous "malefactors" by all necessary means ${ }^{125}$. In implementing their program, Taine maintained, the Jacobins drew justification from "an axiom of political geometry which constituted its own proof." The Jacobins did not see their opponents as "real human beings": "[The revolution] did not see them; it had no need to see them; with eyes closed, it ground this human material into dust"126.

In Leontovitsch's opinion, Ivan IV was a kind of Jacobin avant la lettre. What distinguished Ivan from his contemporaries was not his theocratic absolutism per se, but rather his will to impose that ideology on the country. According to Leontovitsch, "Ivan was consequent, others were not. He wanted to incorporate the idea into reality rigorously and uncompromisingly, while others confined themselves to judging existing reality on the basis of ideology"127. Ivan upheld a theology of autocratic sovereignty, just as Jacobins fashioned an ideology of revolutionary sovereignty. In Taine's formulation, Ivan transformed himself in a fashion resembling "the way a theologian becomes an inquisitor" 128 .

If the tsar's ideological views never changed, what accounted for the different periods of his reign? According to Leontovitsch, "the tsar didn't change, but the milieu in which he worked did; the tsar's politics didn't change, but the reaction of this milieu did"129. Ivan's opponents, such as Metropolitan Filipp and Prince Kurbskii, shared his political assumptions, and therefore they could offer only moral objections to his methods of absolute rule. Leontovitsch compared the fecklessness of the clerical-aristocratic opposition to the "helplessness" of the modern bourgeoisie in its encounter with socialism ${ }^{130}$. As the tsar's critics pressed their case against his "pride and fanaticism," Ivan's determination to have his way intensified. To capture this turn, Leontovitsch quoted Mikhail Osipovich Gershenzon's description of the Russian-intellectual-turned-Catholic-priest, Vladimir Sergeevich Pechorin: "The closer he [Pechorin] came to his ideal, the crueler his heart grew"131.

Leontovitsch contended that, over time, as Ivan's anti-aristocratic impulse more deeply impacted Muscovite politics, the aristocrats' opposition sharpened. In effect, Leontovitsch argued, there occurred a dialectical process in which criticism of the tsar led him to greater cruelties, and these "fanatical" methods of rule further reinforced the opposition to him. As a consequence, the old "subjective" notions of aristocratic rights vanished into the air, and a new "objective" order based on state service took shape ${ }^{132}$.

Leontovitsch traced the tsar's anti-aristocratic thinking to early moments in his reign: to Adashev's advice "never to fear the strong and the titled"133; to Ivan's efforts at the Sto-

124 Ibid. S. 72. fn. 1.

125 Ibid. S. 83. fn. 1. See: Taine H. Les origines de la France contemporaine. 27 éd. Vol. 5. Paris, 1911. P. 36 .

126 Leontovitsch V. V. Die Rechtsumwälzung... S. 85, fn. 2; Taine H. Les origines... P. 23.

127 Leontovitsch V. V. Die Rechtsumwälzung... S. 86.

128 Ibid. S. 87; Taine H. Les origines... Vol. 5. P. 37.

129 Leontovitsch V. V. Die Rechtsumwälzung... S. 89.

130 Ibid. S. 90.

131 Ibid. S. 93; Gershenzon M. Zhizn' M. S. Pechorina. Moscow, 1910. P. 105.

132 Leontovitsch V. V. Die Rechtsumwälzung... S. 95-96.

133 Ibid. S. 99. 
glav council to support the poor, the elderly and victims of war ${ }^{134}$; to Ivan's candid declaration that, in his childhood, boyars had tried to wield power in their own interest ${ }^{135}$; to Ivan's decision to limit the principle of mestnichestvo in staffing the army ${ }^{136}$. Ivan reduced the boyars' influence in the state apparatus and the army, "while leaving the private interests of the boyars more or less undisturbed" 137 .

On 20 September 1556, however, Ivan ordered every possessor of hereditary landed property to supply a horse to the army for each hundred cheti of arable land in his possession. According to Leontovitsch, the 1556 decree flowed directly from the tsar's commitment to defend his subjects against external aggression, and therefore it rested on a bedrock ideological principle of theocratic absolutism ${ }^{138}$. Because the decree encumbered the boyars' landed estates [votchiny] in unprecedented fashion and therefore undermined their "subjective" rights as a group immune from taxation, it constituted the beginning of a new social order in Muscovy ${ }^{139}$, an order that "degraded" boyars to the level of the service nobility. Most boyars regarded the decree as a challenge to their social pre-eminence, and thus, following Kurbskii's example, they intensified their opposition to Ivan. They called at court for the revocation of the "unbearable" 1556 decree ${ }^{140}$.

Leontovitsch noted that Ivan had issued the decree at a pivotal military junction just after the sacking of Astrakhan and after the army's devastation of the Tatar Horde: at this moment, the boyars could not easily prey on popular discontent with the victorious tsar. Leontovitsch wrote that, "On this occasion as well, a despotic leader used an external threat to undercut his subjects' rights" 141 . This remark linking war, despotism and assaults on civil rights was probably an oblique reference to the Russian revolution and to Nazi Germany.

Leontovitsch contended that the tsar's attempt to enforce the 1556 decree "entailed fundamental difficulties that led ultimately to the establishment of the oprichnina"142. In Leontovitsch's telling, the oprichnina was an attempt, by means of state terror, to resettle small-holding service nobles on boyars' confiscated lands, but it was also a social war against the boyars, even against those who had obeyed the 1556 decree. In Leontovitsch's opinion, therefore, the oprichnina was a "genuine revolution"; an attempt by the tsar to establish a "new, ideal, objective social order"; a social transformation in which Ivan made use of previously marginal people now hungry to seize opportunities the state offered them ${ }^{143}$. Leontovitsch quoted Hauriou's comment on the fate of religious reformers who had announced a "beautiful sounding program" only to find themselves surrounded by confidence men and thieves, and to witness their splendid plans degenerating into something "mediocre, awful and lamentable"144.

134 Ibid. S. $99-101$.
135 Ibid. S. $101-102$.
136 Ibid. S. $102-103$.
137 Ibid. S. 104.
138 Ibid. S. $106-109$.
139 Ibid. S. $106-107$.
140 Ibid. S. $109-110$.
141 Ibid. S. 110.
142 Ibid. S. 113.
143 Ibid. S. 114.
144 Ibid. S. $114-115 ;$ Hauriou M. La science sociale traditionnelle. Paris, 1896. P. 191. 
Leontovitsch interpreted the oprichnina not as an unsuccessful attempt to restore the best features of the Kievan federation with its service-based property arrangements, but as a successful revolution that laid foundations for the serf system, which dominated Russia's future until $1861^{145}$. According to this interpretation, the establishment of state service in 1556 as a prerequisite for use of landed property led, in the next decades, to fixing peasants on the land: in other words, the spread of the pomestie system among the social elites was the logical first step toward the nadel system, which gave peasants use of pomestie land contingent on payment of dues or performance of duties. In the process of this development, Leontovitsch suggested, uncontingent ownership of property virtually disappeared in Russia. In his terms, "consequently, the abolition of the titled aristocrats' private landed property led swiftly to the general abolition of landed property [in Muscovy]"146.

Leontovitsch held that the serf system did not appear accidentally, but rather as a result of the "rationalizing tendency" stemming from Ivan's determination to subordinate all his subjects to the state and to transform material goods into instruments of state con$\operatorname{trol}^{147}$. In Leontovitsch's opinion, Ivan IV had laid the foundation for subsequent centuries of Russian history. The tsar's "binding" [prikreplenie] of Russian nobles to state service and of peasants to the land in the sixteenth century triggered centuries later a countervailing process - the "unbinding" [raskreposchchenie] of society and peasantry from their obligations. Leontovitsch asserted that the "unbinding" of individuals' obligations was "the essence of Russian liberalism." He also linked the serf system to the rise of Russian socialism $^{148}$. Thus, all of Russia's subsequent history stemmed from Ivan's ideological assumptions and from his "relentless, fanatically impatient, uneasy spirit"149.

Was Leontovitsch's book a reaction against the official Soviet tendency in the 1930s and early 1940s to idealize Ivan IV?

Maureen Perrie has noted that, by the mid-1930s, Soviet cultural authorities had begun to turn against earlier interpretations of history emphasizing tsarist oppression and the wickedness of Russian foreign policy: the perceived need to foster patriotism to hold the populace together in case of war now led to "a reversion to older approaches to history, which emphasized the role of individual 'great men' as national heroes" ${ }^{\prime 50}$. Perrie has argued that the new interpretive scheme celebrating great patriots emerged gradually. At first, in the mid-1930s, cultural leaders constructed heroic analogies between efforts of earlier Russian patriots to resist foreign invaders, and efforts by the Soviet government to ready the workers' state to fight the country's enemies in Europe and Asia. Later, in the winter 1940-1941, the campaign to find historical analogues for Soviet patriotism reached a new stage: at Stalin's initiative, high Soviet officials commissioned various creative works treating Ivan IV as a strong, wise patriotic leader. Among the prominent new works on Ivan were the novelistic trilogy Ivan Groznyi by Valentin Ivanovich Kostylev, the play Ivan Groznyi by Aleksei Nikolaevich Tolstoi, and the monumental films under the same name

145 Leontovitsch V. V. Die Rechtsumwälzung... S. 115-116.

146 Ibid. S. 117-118.

147 Ibid. S. 118.

148 Ibid. S. 120.

149 Ibid.

150 Perrie M. The Cult of Ivan the Terrible in Stalin's Russia. Houndmills, Basingstroke, Hampshire, 2001. P. 192. A similar point can be found in: Brandenberger D. National Bolshevism: Stalinist Mass Culture and the Formation of Modern Russian National Identity. Cambridge (Mass.), 2002. 
by Sergei Mikhailovich Eisenshtein ${ }^{151}$. The authorities expected the new works to show Ivan as "people's tsar" aligned with peasants and other commoners against treacherous boyars. By highlighting the historical necessity to defend the state against external and internal foes, the new work was supposed to justify the oprichnina. It is easy to see how such a flattering portrait of Ivan supported Stalin's iron rule, the purges of the late 1930s, and Soviet absorption of the Baltic states after 1939. Perrie has rightly classified the tsar's rehabilitation as "the Stalinization of Ivan the Terrible"152.

It is unlikely, however, that the Soviet rehabilitation of Ivan IV had a direct impact on Leontovitsch's view of his subject. Kostylev's novel appeared in installments from 1944 to 1947, and Tolstoi's play was staged only in 1944 - that is, long after Leontovitsch had started writing his book. The first part of Eisenshtein's film Ivan Groznyi premiered only in January 1945; the second part, which dealt with the oprichnina, was not released until $1958^{153}$. It is conceivable, of course, that news of the official campaign to rehabilitate Ivan IV reached Leontovitsch in March 1941, when he might have read Kostylev's article on Ivan in Izvestiia ${ }^{154}$. Leontovitsch may also have caught the drift of official Soviet thinking on Ivan even earlier, from V. G. Verkhoven"s 1939 essay, Russia in the Age of Ivan Groznyi, which stressed the impact of the boyar "treason" against the crown ${ }^{155}$. But the evidence in Leontovitsch's book on Ivan suggests that he reacted not to the Soviet "Stalinization of Ivan the Terrible," but rather to two earlier "waves" of scholarship on Ivan.

A major impact on Leontovitsch's thinking about Ivan probably came from scholarship in the half-century from 1880 to 1930. Leontovitsch closely studied Mikhail Aleksandrovich Diakonov's 1889 essay on political ideas in Old Russia, a book which underlined the importance of Ivan IV's emphasis on the tsar's sacred authority inside Muscovy and also outside it, amongst Christian rulers ${ }^{156}$. Leontovitsch must have been familiar with Sergei Fedorovich Platonov's 1899 essays on the Time of Troubles, essays which underscored long-term developments making Muscovite grand dukes into "popular/national leaders" [narodnye vozhdi], and which stressed the tension between the boyars and the crown ${ }^{157}$. Platonov described the oprichnina as a "political coup" [gosudarstvennyi perevorot] against the boyars ${ }^{158}$ - a view Leontovitsch came to share - but also as an attempt

${ }^{151}$ Kostylev V. I.: 1) Ivan Groznyi (Moskva v pokhode). Moscow, 1944; 2) Ivan Groznyi (More). Moscow, 1945; 3) Ivan Groznyi (Nevskaia tverdynia). Moscow, 1947. For Tolstoi’s play, see: Tolstoi A. N. Ivan Groznyi. Dramaticheskaia povest' v dvukh chast'iakh. Moscow, 1944.

152 Perrie M. The Cult... P.77-178.

153 The Soviet Artistic Council viewed Eisenshtein's original cut of Ivan Groznyi, Part Two, in February 1946, but blocked its public release. On 24 February 1947, Eisenshtein and the actor Nikolai Konstantinovich Cherkasov, who played Ivan in the films, met Stalin, Andrei Aleksandrovich Zhdanov and Viacheslav Mikhailovich Molotov in the Kremlin to discuss possible changes in the film, but Eisenshtein did not manage to complete the editing before his death in February 1948. See: Perrie M. The Cult... P. 170-178; Mar'iamov G. B. Kremlevskii tsenzor (Stalin smotrit kino). Moscow, 1992. P. 84-92, gives a text of the conversation between Eisenshtein and Stalin. For the production history of the film, see: Neuberger J. Ivan the Terrible. London; New York, 2003. P. 13-24.

154 Kostylev V.I. Literaturnye zametki // Izvestiia. 1941. 19 March. P. 4.

155 Perrie M. The Cult... P. 81-82; Verkhoven' V. G. Rossiia v tsarstvovanie Ivana Groznogo. Moscow, 1939. According to Perrie, Verkhoven"s essay was published in a mass edition of 100,000 copies.

156 Diakonov M. A. Vlast' Moskovskikh gosudarei. Ocherki iz istorii politicheskikh idei drevnei Rusi do kontsa XVI veka. St. Petersburg, 1889. P. 136-144.

157 Platonov S. F. Ocherki po istorii smuty v Moskovskom gosudarstve XVI-XVII vv. $3^{\text {rd }}$ ed. St. Petersburg, 1910. P. 120-128.

158 Ibid. P. 130. 
"to undermine everything in the state that supported aristocratic landholding"159. In a sense, Platonov anticipated Leontovitsch's contention that Ivan sought to obliterate private or "subjective" law by destroying its source - local principalities ${ }^{160}$. Platonov made the argument that the oprichnina, by driving peasants out of their homes near Moscow, eventually prompted the state to try to "fix" peasants to the land ${ }^{161}$. Platonov repeated his main interpretive claims about Ivan in his 1924 biography of the tsar ${ }^{162}$, a book Leontovitsch cited several times in his study of Ivan IV. Diakonov also repeated Platonov's ideas on the peasantry in his 1904 book on the political and social structure of Old Russia ${ }^{163}$, a volume Leontovitsch would likely have known but did not cite in his book on Ivan IV.

Another key interpretation of Ivan IV came from Robert Iur'evich Vipper's 1922 biographical essay Ivan Groznyi ${ }^{164}$, which classified Ivan as a military monarch trying to overcome the fragmentation of aristocratic principalities ${ }^{165}$ and to build in their place a unitary state ${ }^{166}$. Vipper used the term "autocratic-communist" to describe the pivotal 1556 reforms ${ }^{167}$. As Perrie has noted, the medievalist Ivan Ivanovich Polosin adopted Vipper's term when he compared Ivan's "revolution" to the events of $1917^{168}$. It is not clear whether Leontovitsch read Vipper's book or Polosin's discussion of the oprichnina by Heinrich von Staden; if he did, consulting these books may have prompted him to conclude that Ivan's economic policy anticipated Soviet "absolutism." In any case, we know from two sources that Leontovitsch was familiar with Vipper's and Polosin's arguments ${ }^{169}$.

A crucial reference for Leontovitsch was Georgii Petrovich Fedotov's 1928 book on the Metropolitan Filipp ${ }^{170}$. In it, Fedotov highlighted the bloody confrontation between Ivan and Filipp, a confrontation that proved to Fedotov's satisfaction that the oprichnina was tyrannical. Fedotov maintained that Ivan's policies, whatever their secular justifications, were "immoral." In fact, the policies were manifestations of Ivan's psychological "abnormality" [nenormal'nost']. The historian also pointed out that, from the Russian nationalist perspective, the oprichnina was a disaster, because it contributed to Muscovy's defeat in the Livonian war. In a sense, Fedotov's moralistic reading of Ivan's reign constituted a return to Karamzin's early nineteenth-century understanding of Ivan as a tyrant. As we

159 Ibid. P. 142-143.

160 Ibid. P. 147-148.

161 Ibid. P. 158

162 Platonov S. F. Ivan Groznyi. Berlin, 1924.

163 Diakonov M. A. Ocherki obshchestvennago i gosudarstvennago stroia drevnei Rusi. $2^{\text {nd }} \mathrm{ed}$. St. Petersburg, 1908. P.343-348.

164 Vipper R. I. Ivan Groznyi. Moscow, 1922.

165 Ibid. P. 103-131; see the intelligent remarks on Vipper's book by: Perrie M. The Cult... P. 12-13.

166 Ibid. P. 13-14.

167 Vipper R. I. Ivan Groznyi. P. 138.

168 Polosin called Ivan's domestic policy "military-autocratic communism" [voenno-samoderzhavnyi kommunizm]. See: Polosin I.I. Zapadnaya Evropa i Moscovija v XVI veke // Shtaden G. O Moskve Ivana Groznogo. Zapiski nemtsa oprichnika / ed. by I.I. Polosin. Leningrad, 1925. P.40; Perrie M. The Cult... P. $16-17$.

169 Leontovitsch's bibliography for Die Rechtsumwälzung unter Iwan der Schrecklichen referred neither to Vipper nor to Polosin's 1925 edition of Heinrich von Staaden. Leontovitsch would have known of Vipper's book and interpretation from Platonov's Ivan Groznyi, which commented on Vipper. For von Staaden, Leontovitsch used the 1930 German edition: Staaden H. von. Aufzeichnungen über den Moskauer Staat: nach der Handrschrift des Preussischen Staatsarchivs in Hannover / Hrsg. von F. Epstein. Hamburg, 1930. However, Leontovitsch would have known of Polosin's interpretation of Ivan IV from the historiographical "excursus" at the end of Fedotov's book on the Metropolitan Filipp (see citation below).

170 Fedotov G. P. Sviatoi Filipp, Mitropolit Mokovskii. Paris, 1928. 
have seen, Leontovitsch registered Fedotov's opinions on Ivan's political ruthlessness and psychological imbalance, but rejected Fedotov's suggestion that Ivan's policies were unnecessary or irrational.

The earliest influences on Leontovitsch were perhaps the most profound. Aside from volumes VIII through X of Karamzin's History of the Russian State, which labeled Ivan a tyrant but validated his centralizing policies, Leontovitsch drew on two mid-nineteenth-century historians affiliated with the so-called "juridical school" of historical writing: Boris Nikolaevich Chicherin and Sergei Mikhailovich Solov'ev. These historians treated Ivan's reign as a key moment in the construction of a unified Russian state. For Leontovitsch's purpose, Chicherin's essay on Muscovite charters was emblematic, because Chicherin contrasted the "anarchism" of Old Russia with the "order" of the Muscovite state after Ivan IV ${ }^{171}$. Chicherin's main juridical idea was that the early legal system was based on private law promulgated by local princes, whereas from the mid-sixteenth to the early eighteenth century, there came into existence a system of public law applying to everyone. In his multi-volume history of Russia, Solov'ev treated the oprichnina as regrettable to the degree that it was a manifestation of armed conflict, but he nevertheless saw it as contributing to the central state's victory over fractious boyars ${ }^{172}$. In the end, Solov'ev thought, Ivan's policies constituted an administrative "necessity"173.

In passing we should note that the impact upon Leontovitsch of nineteenth-century Romantic views of Ivan IV, which emphasized the tsar's contradictory, multi-sided personality, is unclear. Natal'ia Nikolaevna Mut'ia has shown that, in the second half of the nineteenth century, Russian writers and artists elaborated on the Romantic vision of the tsar to construct an even more complex portrait of Ivan capturing his heroic, quotidian, arrogant, democratic, religious and brutal aspects. She has suggested that the tsar's cruelty, when refracted in works of plastic art and theater, "no longer horrified [spectators], but attracted and edified [them]"174. It is possible that, in his Ukrainian childhood, Leontovitsch encountered precisely these aestheticized images of Ivan. Leontovitsch may therefore have recoiled against Ivan's legendary cruelty, while at the same time recognizing the tsar's intellectual consistency.

In Leontovitsch's short book on Ivan IV's "legal revolution," there is much to criticize: Leontovitsch introduced no new sources to historical scholarship; he misread the complicated Iosif Volotskii as a fanatical partisan of Muscovite absolutism; he underestimated the principled differences between Ivan and his chief critics, Kurbskii and Filipp; he exaggerated the importance of the 1556 decree as "trigger" for the oprichnina; he erred in suggesting that the oprichnina was an attempt to destroy the boyar elite ${ }^{175}$; he asserted but never proved that the peasants' enserfment was a consequence of the 1556 decree; he

171 See: Chicherin B. N. Dukhovnyia i dogovornyia gramoty velikikh i udel'nykh kniazei // Obzor istorii russkago prava. Moscow, 1858. P.232-375.

172 Solov'v S. M. Istoriia Rossii s drevneishikh vremen. Kniga vtoraia. Vol. VI-X. St. Petersburg, 1894. P. 135-180; 345-534.

173 Ibid. P. 327-328.

174 Mut'ia N. N. Ivan Groznyi. Istorizm i lichnost' pravitelia v otechestvennom iskusstve XIX-XX vv. St. Peterburg, 2010. P. 451.

175 Nancy Kollman has suggested that Leontovitsch could not have written his book after the wave of Soviet scholarship on the oprichnina between the 1960s and 1990s, because this scholarship established in detail the social profiles of the policy's victims. The most important of the books on this subject belong to Ruslan Grigorevich Skrynnikov. See: Skrynnikov R. G.: 1) Nachalo oprichniny. Leningrad, 1960; 2) Oprichnyi terror. Leningrad, 1969; 3) Tsarstvo terrora. St. Petersburg, 1992. 
was almost surely mistaken in interpreting the Time of Troubles as "an aristocratic counter-revolution" aimed at the undoing of Ivan's legal revolution ${ }^{176}$.

At a deeper level, Leontovitsch's book made a problematic equation between religious postulates concerning the tsar's duties as Christian magistrate and state "ideology," between Ivan's Christian Ideenwelt and the Jacobins' modern rationalistic and rationalizing mentality. No doubt, Leontovitsch's equation of religion and ideology is suggestive. After all, there are functional similarities between religion and ideology: both are cognitive systems that help individuals to interpret the world, to understand their role in the world, and to place normative bounds on individual and collective behavior; both, therefore, shape the political order and set the parameters for virtuous political conduct. Because of these functional similarities, both religion and ideology "fit" Hauriou's ideocratic model of state power, a model that considers the state's institutional "personality" a function of its fundamental assumptions or "idea." In Hauriou's thinking, both religious and ideological mentalités may accommodate charismatic leadership of the sort Ivan manifested, alongside the rationalizing elements of a "revolutionary" worldview like the one Ivan allegedly adopted.

And yet, religion and ideology are different. Orthodoxy focuses on duties of the magistrate and of his subjects for the sake of their salvation; moreover, in Orthodox thinking, virtuous conduct depends on adherence to rules mandated by God. On the other hand, a secular ideology advocates the performance of public duties for the sake of mundane objectives, such as the common good and the defense of the realm against external attack. In secular ideological systems, the matter of an individual's salvation is irrelevant, so long as the individual obeys the sovereign authority. Put another way, in secular polities, custom and law regulate private and public conduct, but these regulations do not always coincide with religious norms governing individual conduct. The difference between religion and ideology is both epistemological (that is, they are distinguished by the different sources from which political precepts and thus political behaviors derive) and functional (that is, religious norms and ideological mandates do not necessarily coincide in substance or in effect). The difference may also be historical, insofar as religious polities preceded secular, ideological polities. If Muscovy was, in fact, a "theocratic absolutism," then Leontovitsch perpetrated an anachronism by reading the ideological mentality back into the sixteenth century.

The virtues of Leontovitsch's book are reverse images of its weaknesses. His emphasis on Ivan's "legal revolution" forced readers to consider whether Russian socialism and the 1917 revolution amounted to echoes of Ivan's earlier, more profound revolution against property. Leontovitsch's term "legal revolution" focused readers' attention on the possibility of a revolution based on statutory innovation as well as on state violence. Finally, Leontovitsch's book on Ivan IV prepared the way for his later book on Russian liberalism, where he defined liberalism's method as the "unfettering" or "unbinding" of the individual. Both books flowed from a comprehensive conception of the Russian historical process that Leontovitsch had painstakingly worked out in Prague, Paris and Berlin.

176 This point about the Time of Troubles can be found in: Leontovitsch V. V. Die Rechtsumwälzung... S. 116, fn. 1. 
In retrospect, it is astonishing that Leontovitsch finished his small book on Ivan IV. Even though he had the benefit of an excellent domestic education in Kiev, of training in the Naumenko school, and then of study in Prague and Paris, his life after 1917 can only be described as a fractured existence. He escaped death in the Volunteer Army, avoided denunciation as a "socially hostile element" in Kiev, reconnected with his family in Prague, and made the best of his educational possibilities in the Russian imperial diaspora only to take up a series of academic posts in Nazi Germany. In Berlin he methodically, and cautiously, made himself into an analyst of Soviet power, a critic of modern dictatorship, and a historian of sixteenth-century Muscovy. In Germany, against considerable odds, he held to his religious beliefs and, with the aid of his wife and others, linked his Orthodox outlook to her Lutheranism. His religious outlook helped him see the errors of National Socialism and to grasp what he might do in his scholarship to resist its slogans.

It will not do to describe Leontovitsch's intellectual network in the 1930s and 1940s his quiet friendship with Makarov, his admiration for Chizhevskii and Stepun - as a political or intellectual "circle," for that word implies the possibility of regular meetings to exchange ideas. Nor was his network a political "cell": so far as we know, Leontovitsch belonged to no political party and cannot even be said to have taken part in a political "movement." He and other members of the imperial diaspora who rejected both Soviet power and National Socialism were, in spite of their similarity of outlooks, frighteningly alone. Perhaps that is a common fate of decent human beings in dark times.

\section{References}

Beliaev I. D. Lektsii po istorii russkago zakonodatel'stva. Moscow, Tipo.-Lit. S. A. Petrovskogo i N.P. Panina Printing House., 1879, 730 p. (In Russian)

Berkefeld W. Malen'kii kruzhok v Galle. D. I. Chizhevskii. Izbrannoe. In 3 vols. Vol. I. Materialy k biografii (1894-1977). Moscow, Biblioteka-fond "Russkoe zarubezh'e" - Russkii put' Publ., 2007, pp. 309-315. (In Russian)

Brandenberger D. National Bolshevism: Stalinist Mass Culture and the Formation of Modern Russian National Identity. Cambridge (Mass.), Harvard University Press, 2002, 378 p.

Chicherin B. N. Dukhovnyia i dogovornyia gramoty velikikh i udel'nykh kniazei. Obzor istorii russkago prava. Moscow, Izdanie K. Soldatenkova i N. Shchepkina, 1858, 389 p. (In Russian)

Chicherin B. N. Oblastnye uchrezhdeniia Rossii v XVII-m veke. Moscow, Publishing House of Aleksandr Semen, 1856, 606 p. (In Russian)

Diakonov M. A. Ocherki obshchestvennago i gosudarstvennago stroia drevnei Rusi, $2^{\text {nd }}$ ed. St. Petersburg, Pravo Publ., 1908, 527 p. (In Russian)

Diakonov M. A. Vlast' Moskovskikh gosudarei. Ocherki iz istorii politicheskikh idei drevnei Rusi do kontsa XVI veka. St. Petersburg, Printing House of I. N. Skorokhodova, 1889, 227 p. (In Russian)

Fedotov G. P. Sviatoi Filipp, Mitropolit Moskovskii. Paris, YMCA Press, 1928, 224 pp. (In Russian)

Gershenzon M. Zhizn' M. S. Pechorina. Moscow, Put' Publ., 1910, 233 p. (In Russian)

Golubinskii E. E. Istoriia russkoi tserkvi. In 2 vols, 4 pts. Vol. I. Period Pervij. Kievskij ili domongol'skij. Pervaja polovina toma. Moscow, Imperatorskoe obschchestvo istorii i drevnostei rossiiskikh Publ., 1901, 969 p. (In Russian)

Golubinskii E. E. Istoriia russkoi tserkvi. In 2 vols, 4 pts. Vol. I. Period Pervij. Kievskij ili domongol'skij. Vtoraja polovina toma. Moscow, Imperatorskoe obschchestvo istorii I drevnostei rossiiskikh Publ., 1904, 926 p. (In Russian)

Golubinskii E. E. Istoriia russkoi tserkvi. In 2 vols, 4 pts. Vol. II. Period Vtoroj Moskovskii. Ot nashestvija mongolov do mitropolita Makarija vkliuchitelno. Pervaja polovina toma. Moscow, Imperatorskoe obschchestvo istorii i drevnostei rossiiskikh Publ., 1900, 919 p. (In Russian) 
Golubinskii E. E. Istoriia russkoi tserkvi. In 2 vols, 4 pts. Vol. III. Period Vtoroj Moskovskii. Ot nashestvija mongolov do mitropolita Makarija vkliuchitelno. Vtoraja polovina toma. Moscow, Imperatorskoe obschchestvo istorii i drevnostei rossiiskikh Publ., 1911, 616 p. (In Russian)

Hauriou M. La science sociale traditionnelle. Paris, L. Larose Publ., 1896, 432 p.

Hufen C. Fedor Stepun. Ein politischer Intellektueller aus Russland in Europa. Die Jahre 1884-1945. Berlin, Lukas Verlag Publ., 2001, 583 S.

Kapterev N.F. Svetskie arkhereiskie chinovniki drevnei Rusi. Moscow, Tipografiia Sovremennye izvestiia, 1874, 236 p. (In Russian)

Korthaase W. Chto proiskhodilo s glavnym sochineniem Komenskogo 'Consultatio catholica's 1934 po 1945 god. D. I. Chizhevskii. Izbrannoe. In 3 vols. Vol. I. Materialy k biografii (1894-1977). Moscow, Biblioteka-fond "Russkoe zarubezh'e" - Russkii put' Publ., 2007, pp. 316-327. (In Russian)

Korthaase W. Dmitrii Chizhevskii i rodina ego vybora Germaniia. Slavonic Library at the National Library of the Czech Republic. Dmytro Čyževskyj, osobnost a dílo: sborník př́spěvků z mezinárodní konference poŕádané Slovanskou knihovnou při Národní knihovně ČR... 13.-15. června 2002 v Praze. Red. Z. Rachůnkova. Prague, Narodni knihovna ČR Publ., 2004, pp. 101-128. (In Russian)

Leontovitsch V.V. Die Rechtsumwalzung unter Iwan dem Schrecklichen und die Ideologie der russischen Selbstherrschaft. Stuttgart, Kohler Publ., 1946, 134 S.

Luganov N. [pseudonym, Stepun F.] Pis'mo iz Germanii (Formy nemetskogo sovetofil'stva). Sovremennye zapiski, 1930, vol. XLIV, pp. 448-463. (In Russian)

Luganov N. [pseudonym, Stepun F.] Pis'ma iz Germanii (Natsional' sotsialisty). Sovremennye zapiski, 1931, vol. XLV, pp. 446-474. (In Russian)

Luganov N. [pseudonym, Stepun F.] Pis'ma iz Germanii (Vokrug vyborov presidenta respubliki). Sovremennye zapiski. 1932, vol. XLIX, pp. 402-421. (In Russian)

Makarov A. N. Liga natsii. Petrograd, Academia Publ., 1922, 77 p. (In Russian)

Makarov A. N. Osnovnye nachala mezhdunarodnogo chastnogo prava. Moscow, [s. n.], 1924, 146 p. (In Russian)

Makarov A. N. Osnovnye nachala mezhdunarodnogo chastnogo prava. Moscow, Knigodel Publ., 2005, 184 p. (In Russian)

Makarov A.N. Pravovoe polozhenie inostrantsev v SSSR. Moscow, Iuridicheskoe izdatel'stvo Narkomiusta RSFSR, 1924, 52 p. (In Russian)

Makarov A. N. Das russische Zwischenprivatrecht (internationales Privatrecht). Berlin; Breslau, H. Sach Publ., $1926,100 \mathrm{p}$.

Makarov A. N., Loewenfeld W. Das internationale Privatrecht der europäischen und auseuropäischen Staaten. Berlin, C. Heymann Publ., 1929, 458 S.

Mar'iamov G. B. Kremlevskii tsenzor: Stalin smotrit kino. Moscow, Konfederatsiia soiuzov kinematografistov "Kinotsentr" Publ., 1992, 127 p. (In Russian)

Mann T. Betrachtungen eines Unpolitischen. Berlin, S. Fischer Publ., 1918, 611 S.

Mut'ia N. N. Ivan Groznyi. Istorizm i lichnost' pravitelia votechestvennom iskusstve XIX-XX vv. St. Petersburg, Aleteiia Publ., 2010, 495 p. (In Russian)

Neuberger J. Ivan the Terrible. London; New York, I. B. Tauris Publ., 2003, 96 p.

Oswalt J. Zwischen den Welten 1934-1953. Kriegskindheit und nachkriegsjugend in Zwei Welten. Deutsche und Russen blicken zurück. Hrsg von. B. Bonwetsch. Essen, Klartext Publ., 2009, Ss. 33-48.

Patocka J. O komenologicheskikh trudakh Dmitriia Chizhevskogo. D. I. Chizhevskii. Izbrannoe. In 3 vols. Vol. I. Materialy k biografii (1894-1977). Moscow, Biblioteka-fond "Russkoe zarubezh'e" - Russkii put' Publ., 2007, pp. 328-336. (In Russian)

Perrie M. The Cult of Ivan the Terrible in Stalin's Russia. Houndmills; Basingstroke, Palgrave Publ., 2001, $255 \mathrm{p}$.

Platonov S. F. Ivan Groznyi. Berlin, Obelisk Publ., 1924, 641 p. (In Russian)

Platonov S. F. Ocherki po istorii smuty v Moskovskom gosudarstve XVI-XVII vv., $3^{\text {rd }}$ ed. St. Petersburg, Sklad izdaniia u Ia. Bashmakova i Ko. Publ., 1910, 642 p. (In Russian)

Pokrovskii I. M. Russkie eparkhii v XVI-XVII vv., ikh otkrytie, sostav i predely: opyt tserkovno-istoricheskago, statisticheskago i geograficheskago izsledovaniia. Kazan', Tipo-Lit. Imperatorskago Universiteta, 1897, 553 p. (In Russian)

Polosin I.I. Zapadnaya Evropa i Moscovija v XVI veke. G. Shtaden. O Moskve Ivana Groznogo. Zapiski nemtsa oprichnika. Ed. by I. I. Polosin. Leningrad, Izdanie M. i S. Sabashnikovykh, 1925, pp. 9-53. (In Russian)

Skrynnikov R. G. Nachalo oprichniny. Leningrad, Leningrad University Press, 1966, 417 p. (In Russian)

Skrynnikov R. G. Oprichnyi terror. Leningrad, Leningrad University Press, 1969, 350 p. (In Russian) 
Skrynnikov R. G. Tsarstvo terrora. St. Petersburg, Nauka Publ., 1992, 574 p. (In Russian)

Solov'ev S. M. Istoriia Rossii s drevneishikh vremen. Kniga vtoraia. Vol. VI-X. St. Petersburg, Tovarishchestvo "Obshchestvennaia Pol'za" Publ., 1894, 871 p. (In Russian)

Stefanovich D. O Stoglave: Ego proiskhozhdenie, redaktsii $i$ sostav: $k$ istorii pamiatnikov drevnerusskago tserkovnago prava. St. Petersburg, Leont'ev Publ., 1909, 320 p. (In Russian)

Stepun F. Byvshee i nesbyvsheesia. Moscow; St. Petersburg, Progress-Litera Publ.; Aleteiia Publ., 1995, 651 p. (In Russian)

Stepun F. Das Antlitz Russlands und das Gesicht der Revolution. Bern; Leipzig, Gotthelf Verlag Publ., 1934, $104 \mathrm{~S}$.

Stepun F. Das Antlitz Russland und das Gesicht der Revolution. Aus meinem Leben 1884-1922. München, 1961, 509 S.

Stepun F. Iz pisem praporshchika artillerista. Prague, Plamia Publ., 1926, 267 p. (In Russian)

Stepun F. Khristianstvo i politika. Sovremennye zapiski, 1933, vol. LIII, pp. 335-352. (In Russian)

Stepun F. Khristianstvo i politika. Sovremennye zapiski, 1934, vol. LV, pp. 308-325. (In Russian)

Stepun F. Mysli o Rossii. Sovremennye zapiski, 1923, vol. XV, pp. 281-296. (In Russian)

Stepun F. Mysli o Rossii. Sovremennye zapiski, 1924, vol. XXI, pp. 279-304. (In Russian)

Stepun F. Mysli o Rossii. Sovremennye zapiski, 1925, vol. XXIII, pp. 342-371. (In Russian)

Stepun F. Osval'd Shpengler i Zakat Evropy. Osval'd Shpengler i Zakat Evropy. Eds N.A.Berdiaev, J.M. Bukshpan, F. A. Stepun, S. L. Frank. Moscow, "Berg" Publ., 1922, pp. 5-33. (In Russian)

Stepun F. Pis'ma. Ed. by V.K. Kantor. Moscow, ROSSPEN Publ., 2013, 683 p. (In Russian)

Stepun F. The Russian Soul and the Revolution. Transl. by E. Huntress. New York; London, Charles Scribner's Sons Publ., 1935, 184 p.

Stepun F. Wladimir Solowjew. Leipzig, F. Eckhart Publ., 1910, 132 S.

Taine H. Les origines de la France contemporaine. Vol. 5. Paris, Hachette et Cie Publ., 1911, 327 p.

Vladimirovskii-Budanov M.F. Obzor istorii russkago prava. St. Petersburg; Kiev, [s.n], 1888, 542 p. (In Russian)

Verkhoven' V. G. Rossiia v tsarstvovanie Ivana Groznogo. Moscow, Gospolitizdat, 1939, 56 p. (In Russian)

Vipper R. Iu. Ivan Groznyi. Moscow, Del'fin Publ., 1922, 116 p. (In Russian)

Received: 10.08.2017

Accepted: 30.03.2018 